\title{
A VIOLÊNCIA QUE INSISTE EM PERMANECER
}

O primeiro número do ano de 2000 da revista OIKOS: Família e Sociedade em Debate apresenta artigos que compõem o dossiê Violência e seus múltiplos aspectos. Essa temática é relevante porque o Brasil está entre os dez países mais violentos do mundo. O Atlas da Violência (IPEA, 2019) mostra que a violência letal acomete principalmente a população jovem, entre 15 a 19 anos, bem como a grupos específicos, notadamente negros, mulheres e a população LGBTI. Os dados revelam que, durante a década de 2007 a 2017, houve um crescimento dos homicídios femininos no Brasil, chegando a cerca de 13 assassinatos por dia. Confirmando a desigualdade racial no Brasil, 75,5\% das vítimas de homicídios eram pretos ou pardos. Em relação à população LGBT, os índices são mais difíceis de serem contabilizados nas estatísticas, pois o IBGE não questiona a orientação sexual das pessoas. Entretanto, dados do Disque 100 e do Sinan (Sistema de Vigilância de Violências) revelam um aumento da violência contra a população LGBTI+, sobretudo após 2016.

Diante da importância do tema, este dossiê traz em sua capa três pinturas da artista plástica gaúcha Graça Craidy, que capta com profunda sensibilidade as múltiplas faces da violência que frequentemente resulta em morte. Como destaca a artista:

As duas imagens coloridas fazem parte da série "Até que a morte nos separe", pintadas a partir de fotos reais das cenas de crimes de feminicídios [...]. São mulheres brasileiras, de várias partes do país, que foram assassinadas pelos maridos. A obra em preto e branco, da mulher negra com o olho roxo, é da série "Livrai-nos do Mal", de onde denuncio a violência física contra a mulher. (GRAÇA CRAIDY, 21/04/2020).

As pinturas de Graça Craidy traduzem a dor, o desespero e a indignação de mulheres violentadas sexualmente, espancadas e assassinadas por seus companheiros, resultado do poder e do machismo que insistem em permanecer mesmo diante da luta pela igualdade e da legislação de proteção às mulheres.

As múltiplas faces das diferenças de gênero que acometem mulheres de norte a sul do país indicam que o Brasil não exorcizou os fantasmas da desigualdade de gênero. Por isso, ainda há muito trabalho a ser feito, tanto em termos de militância, quanto de instrumentos de planejamento e gestão pública. 
Neste dossiê, os autores trazem análise sobre violência doméstica, contra mulheres e idosos. Também traz reflexões sobre medidas sócio-educativas para adolescentes infratores bem como sobre a relação entre gênero e cárcere.

No artigo Óbitos violentos e tentativas de suicídio por intoxicação exógena em mulheres, Cristiane Melo, Thaís Oliveira, Marcela Soares e Paula Bevilacqua discutem a violência contra a mulher como um grave evento social e de saúde pública, uma vez que o feminicídio é a expressão mais extrema da violência de gênero. A partir de dados do sistema de informação em saúde, as autoras problematizam as tentativas de suicídio e os óbitos por suicídio decorrentes da violência doméstica. Também destacam que as vítimas são predominantemente mulheres pobres, pretas ou pardas, de pouca escolaridade e de baixa remuneração.

Ana Pereira dos Santos e Luciano Rodrigues Costa, no artigo A lei Maria da Penha e os desafios da atuação policial, discutem a construção da queixa de violência doméstica de mulheres no cotidiano de uma delegacia de polícia. Os autores problematizam o confronto entre a resposta coercitiva que tradicionalmente marcou o lugar social da polícia brasileira e a legislação instituída após 2006. Embora a legislação desafie a polícia a incorporar novas aprendizagens em seu cotidiano profissional, suas práticas revelam representações conservadoras de gênero que dificultam às mulheres o acesso à proteção social.

Na discussão sobre Entraves à implementação da política de enfrentamento à violência contra mulheres: um problema de governança pública, Victor Pereira Avelino discorre sobre o processo de implementação de políticas públicas de enfrentamento à violência contra mulheres no Brasil. Analisando boletins de ocorrência, o autor destaca o desafio para coordenar os diversos setores e níveis de governança em órgãos e entidades da administração pública, onde as burocracias criam entraves à sua implementação.

No artigo Percepções de profissionais sobre a violência contra as mulheres nos serviços de proteção no município de São João del-Rei - MG, Ana Caroline Matos Soares e Márcia Barroso Fontes, a partir de dados da Delegacia Especializada no Atendimento à Mulher, discutem alguns entraves institucionais no enfrentamento da violência contra a mulher, como a ausência de capacitação e especialização dos profissionais, inexistência de uma rede articulada e escassez de ações municipais baseadas na Política e no Pacto Nacional.

Yara Singulano e Karla Teixeira, no texto Percepção de adolescentes sobre as causas da violência doméstica e familiar contra as mulheres, analisam as percepções de adolescentes sobre a violência doméstica e familiar, cometida contra as mulheres, a partir de redações de estudantes do ensino médio de uma escola pública. As principais causas apontadas foram o machismo, o uso de álcool e drogas ilícitas, e as discordâncias familiares ou entre o casal. As 
autoras destacam a necessidade de as escolas discutirem as desigualdades de gênero como causa da violência doméstica, uma vez que a desinformação pode contribuir para a perpetuação do machismo e a naturalização da violência.

Priscilla Marinho, Raquel Uchôa e Laura Duque-Arrazola, por sua vez, problematizam os riscos sociais a que estão submetidos adolescentes que cumprem medida socioeducativa de semiliberdade e discutem a ambivalência entre tutela e responsabilização, no artigo Sociedade de risco e violência: reflexões sobre as práticas de consumo de adolescentes em cumprimento de semiliberdade. Marcados por uma trajetória de segregação e exclusão, os jovens cometem delitos e violência para adquirir objetos de marcas que sinalizam pertencimento social, por possuírem maior poder simbólico. O artigo destaca a dimensão simbólica do consumo, imbricada por questões de violência, pertencimento e condição de classe social.

No artigo Cobertura jornalística sobre a violência com idosos, Débora Teixeira, Rosilene Soares e Rita Farias analisam a cobertura do telejornal Cidade Alerta sobre a pessoa idosa como vítima ou agressora. Perscrutando as chamadas, os temas e os discursos do programa, e articulando-os aos marcadores gênero e classe social, as autoras refletem sobre o sensacionalismo do programa, que contribui para solidificar uma visão negativa da velhice e justifica as práticas violentas contra os idosos, principalmente contra as mulheres.

Finalmente, Felipe da Silva, Raquel Uchôa e Priscilla Marinho desvelam as relações entre modos de vida urbanos, subalternidade, acesso a direitos e limitações decorrentes dos atributos de classe, gênero, etnia/raça e geração, a partir do cotidiano de mulheres que vivenciaram o encarceramento, no artigo Gênero, cotidiano e cárcere. Os resultados revelam a reprodução geracional das trajetórias subalternas das mulheres, que é agravada pela vivência no cárcere e incide sobre as suas subjetividades, relações e acesso a bens e serviços.

Esperamos que a leitura seja agradável e contribua para ampliar os debates em torno da violência no Brasil e subsidiar ações de proteção social.

Rita de Cássia Pereira Farias

Dra em Antropologia e Editora da Oikos 